OPEN ACCESS

Edited by:

Simonetta Corsolini,

University of Siena, Italy

Reviewed by:

Roberto Bargagli,

University of Siena, Italy Miguel Motas,

University of Murcia, Spain

${ }^{*}$ Correspondence:

Tailisi H. Trevizani

taihoppe@gmail.com

Specialty section:

This article was submitted to

Marine Pollution,

a section of the journal

Frontiers in Marine Science

Received: 08 September 2021 Accepted: 22 December 2021

Published: 13 January 2022

Citation:

Trevizani TH, Montone RC and

Figueira RCL (2022) Temporal Distribution of Arsenic and Metals

in Soil From King George Island,

Antarctica. Front. Mar. Sci. 8:772742.

doi: 10.3389/fmars.2021.772742

\section{Temporal Distribution of Arsenic and Metals in Soil From King George Island, Antarctica}

\author{
Tailisi H. Trevizani*, Rosalinda C. Montone and Rubens C. L. Figueira \\ Instituto Oceanográfico, Universidade de São Paulo, São Paulo, Brazil
}

The polar regions are vulnerable to impacts caused by local and global pollution. The Antarctic continent has been considered an environment that has remained little affected by human activities. Direct exposure to contaminants may occur in areas continuously occupied by research stations for several decades. Admiralty Bay on the southeast coast of King George Island, has potential for being affected by human activities due research stations operating in the area, including the Brazilian Commandant Ferraz Antarctic Station (CFAS). The levels of metals and arsenic were determined in soils collected near CFAS (points 5, 6, 7, and 9), Base $\mathrm{G}$ and at two points distant from the CFAS: Refuge II and Hennequin. Samples were collected after the fire in CFAS occurred in February 2012, up to December 2018 to assess the environmental impacts in the area. Al and As were related with Base G. Refuge II and Hennequin can be considered as control points for this region. As a consequence of the accident, the increased levels for $\mathrm{Cd}, \mathrm{Cu}, \mathrm{Pb}$, and $\mathrm{Zn}$, especially at point 9 (inside the CFAS) and in the soil surrounding the CFAS in 2013. The results from 2016 to 2018 demonstrated a reduction in levels of all studied metals near CFAS, which may be related to the leaching of metals into Admiralty Bay; it is thus, being important the continue monitoring soil, sediments, and Antarctic biota.

Keywords: heavy metals, monitoring, spatial distribution, Commandant Ferraz Antarctic Station, Antarctic pollution

\section{INTRODUCTION}

The polar regions are vulnerable to impacts caused by local and global pollution, the contaminant concentrations tend to increase due to natural and anthropogenic inputs (Farías et al., 2007; Bargagli, 2008). Located in the austral polar region, the Antarctic territory is the fifth largest of the continents, with approximately $98 \%$ of the territory covered by ice, and presents unique characteristics due to its geographic isolation (Xuebin et al., 2006). The Antarctic continent has been considered as one of the environments on the planet that remains little affected by direct human activities (Xuebin et al., 2006). Direct exposure to contaminants can occur in areas with continuous occupation by research stations for several decades (Vodopivez et al., 2001; Santos et al., 2005).

Among the contaminants registered in the Antarctic region, metals, and metalloids represent a problem due to their persistence and stability in the environment, toxicity, and accumulation capacity in the biota (Islam and Tanaka, 2004; Bargagli, 2008). Several studies are dedicated to knowing the levels of metals in Antarctic regions, in matrices such as soil, sediments and biota, 
demonstrating the importance of continuous monitoring of human impacts in this extremely relevant ecosystem for the planet (Bargagli, 2008; Ribeiro et al., 2011; Trevizani et al., 2016a, 2018). As the Antarctic territory has few ice-free areas, studies that assess soil quality and metal levels are focused in the vicinity of research stations such as Commandant Ferraz Antarctic Station (Brazil; Santos et al., 2005), McMurdo Station (United States; Crockett, 1998), Artigas Antarctic Scientific Base (Uruguay; Bueno et al., 2018), Jubany-Dallmann Base (Argentina; Farías et al., 2007), O’Higgins Base (Chile; Celis et al., 2015), Zhongshan (China), Progress I and Progress II (Russia), and Law Base (Romania) (Xu et al., 2020).

King George Island in the South Shetlands archipelago is one of the areas with higher potential for being affected by contamination, because of human activities and the high number of research stations (Santos et al., 2005; Ribeiro et al., 2011). Admiralty Bay on the southeast coast of the King George Island is considered part of the Antarctic Specially Managed Area (ASMA) where the impacts produced should be minimized. An unexpected increase in the contamination on King George Island may have occurred after the accidental fire at CFAS on February 25, 2012. In this tragic event, an explosion in the engine room destroyed about $70 \%$ of the Commandant Ferraz Antarctic Station (CFAS; Guerra et al., 2013). In this study, levels of aluminum (Al), arsenic (As), cadmium (Cd), chromium $(\mathrm{Cr})$, copper $(\mathrm{Cu})$, nickel $(\mathrm{Ni})$, lead $(\mathrm{Pb})$, and zinc $(\mathrm{Zn})$ were investigated in soils collected near CFAS and at distant points, after the fire occurred in February 2012, up to January 2018, to assess the temporal distribution of these pollutants and the environmental impacts around the area, results essential to the conservation and management of the region.

\section{MATERIALS AND METHODS}

\section{Study Area and Sampling}

King George Island is the largest island in the South Shetlands archipelago, covering more than $1,300 \mathrm{~km}^{2}$; it is one of the areas with higher potential for being affected by human activities, since it houses eight research stations (Santos et al., 2005; Ribeiro et al., 2011). On the southeast coast of the island is Admiralty Bay; the great ecological importance of the region led to the creation of a site of scientific interest, being considered part of the Antarctic Specially Managed Area (ASMA) and Scientific Committee on Antarctic Research (SCAR) region, where the impacts produced by different countries should be minimized. Three research stations have been operating in the area: Henryk Arctowski (Poland), Commandant Ferraz (Brazil), and Machu Picchu (Peru) (Montone et al., 2001; Ribeiro et al., 2011).

The formation of the South Shetlands archipelago is related to the subduction of the SE-Pacific oceanic crust under the Antarctic continent, presenting volcanic and plutonic rocks, with predominant lithology of mafic volcanic rocks such as basaltandesites (Fourcade, 1960; Machado et al., 2001; Schaefer et al., 2004). A recent study reports that the ice-free areas of the Admiralty Bay have great landscape variability with reference to lithology, topography, soils, and vegetation (Ferrari et al., 2021).
The great diversity of soil types on King George Island is related to different parent materials, influenced by climate change and biological processes, especially the presence of seabird colonies (Zhao and Li, 1996; Navas et al., 2008; Bölter, 2011).

Sampling was conducted at King George Island, in the area immediately surrounding Commandant Ferraz Antarctic Station (CFAS - points \#5, \#6, \#7, and \#9), including Base $\mathrm{G}$, and at two distant points: Hennequin and Refugio II (Figure 1). Sampling was performed between XXX and XXXVII OPERANTAR (austral summer 2012/13 and 2018/19) according to Table 1.

The sampling depth was from 0 to $5 \mathrm{~cm}$, since most of the metals are accumulated in the soil surface. A polyethylene tube with $4 \mathrm{~cm}$ diameter was used to collect the 25 soil samples that were then stored in a previously cleaned container (with nitric acid 5\%) at $-20^{\circ} \mathrm{C}$. Afterward, samples were sieved $(<2 \mathrm{~mm})$, lyophilized until complete dehydration, homogenized (macerated with mortar and pistil), and stored in polyethylene bags until the chemical analyses.

\section{Chemical Analysis}

For the extraction of metals of the soil samples, the EPA 3050b method of acid digestion with nitric acid, hydrogen peroxide, and hydrochloric acid in a heating plate $\left(90^{\circ} \mathrm{C}\right)$ was used for all elements of interest (United States Environmental Protection Agency [USEPA], 1996). The identification and quantification of metals was performed using inductively coupled plasma optical emission spectrometry (ICP-OES - Varian, model 710ES). The certified reference material SS-2 (EnvironMat SS0-2 soil matrix) had a recovery from 70 to $108 \%$. The detection limit of the method (DLM) were: Al $0.31 \mathrm{mg} \mathrm{kg}^{-1}$, As $0.44 \mathrm{mg} \mathrm{kg}^{-1}$, Cd $0.08 \mathrm{mg} \mathrm{kg}^{-1}$, Cr $0.10 \mathrm{mg} \mathrm{kg}^{-1}$, Cu $0.16 \mathrm{mg} \mathrm{kg}^{-1}$, Ni $0.20 \mathrm{mg}$ $\mathrm{kg}^{-1}, \mathrm{~Pb} 0.52 \mathrm{mg} \mathrm{kg}^{-1}$, and $\mathrm{Zn} 0.32 \mathrm{mg} \mathrm{kg}^{-1}$.

\section{Data Analysis}

The results were compared with Brazilian legislation CONAMA Resolution 420/2009, which defines the principle ranges of chemical concentrations, i.e., (i) Prevention Values (PV) indicate the upper limit below which the principal soil functions are sustained and (ii) Research Values (RV) are the concentration levels above which there are direct or indirect potential risks to human health. Accordingly, Conselho Nacional do Meio Ambiente [CONAMA] (2009) targets can also be considered as guidelines values to evaluate the risk to Antarctic biota because of inorganic compounds released to the environment after the fire accident.

Results were evaluated through statistical analysis using the software Statistica (Statsoft), Past 3 (Hammer et al., 2001), and Microsoft Excel where $p<0.05$ was used to define statistical significance. Before performing multivariate analyses, the premises were verified: normality, using the ShapiroWilk test, and homoscedasticity of the data, using the Bartlett test. Since data normalization was not achieved through the logarithmic transformation, the analyses were performed with the initial data (Underwood, 1997).

Analysis of variance (ANOVA) followed by Tukey's HSD test was used to test for differences related to the sampling location 


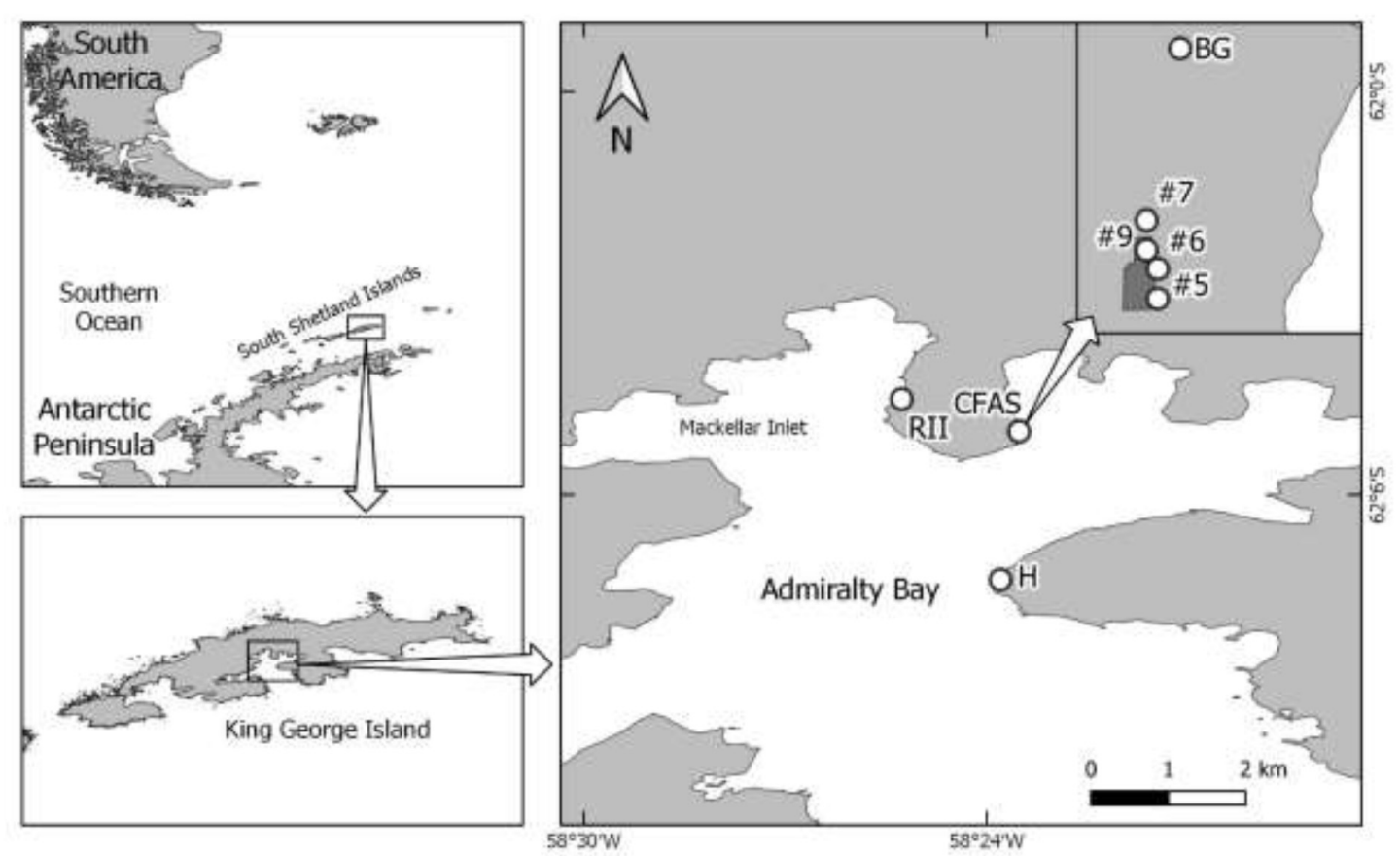

FIGURE 1 | Study area and sampling points (CFAS = Commandant Ferraz Antarctic Station; BG = Base G; RII = Refuge Il; and H = Hennequin) on King George Island, Antarctic.

TABLE 1 | Operantar, period of sampling, identification of year, and location of sampling (CFAS = Commandant Ferraz Antarctic Station; BG = Base G; RII = Refuge II; and $\mathrm{H}=$ Hennequin).

\begin{tabular}{|c|c|c|c|}
\hline Operantar & Period of sampling & Identification of year & Location of sampling \\
\hline$X X X$ & March/2012- 14 days after fire & $2012 a$ & CFAS (\#5, \#6, \#7, and \#9) \\
\hline$X X X$ & March/2012 - 30 days after fire & $2012 b$ & CFAS (\#5, \#6, and \#7) \\
\hline$X X X \mid$ & February - March/2013 & $2013 a$ & CFAS (\#5, \#6, \#7, and \#9), BG, R\|, H \\
\hline$X X X \|$ & November-December/2013 & $2013 b$ & CFAS (\#5, \#6, \#7, and \#9), BG \\
\hline$X X X \mid I$ & January - February/2013 & 2014 & CFAS (\#5, \#6, \#7, and \#9), RII, H \\
\hline XXXIV & December/2015 & 2015 & CFAS (\#5, \#6, \#7, and \#9), BG, RII, H \\
\hline$X X X V$ & December/2016 & 2016 & CFAS (\#5, \#6, \#7, and \#9), BG, RII, H \\
\hline$X X X V I$ & January/2018 & $2018 a$ & CFAS (\#5, \#6, \#7, and \#9), BG, RII, H \\
\hline$X X X V I I$ & December/2018 & $2018 b$ & CFAS (\#5, \#6, \#7, and \#9), BG, RII, H \\
\hline
\end{tabular}

and year on the metal concentrations in soil. As sampling was not performed at the same points in all years, two ANOVAs were performed: (1) only with points close to the CFAS (\#5, \#6, \#7, and \#9) during the period 2012-2018, and (2) with points close to CFAS (\#5, \#6, \#7, and \#9), including Base G, Refuge II and Hennequin during the period 2013-2018. For an integrated analysis of the concentration of metals in soil, and their spatial and temporal distribution, a Principal Component Analysis (PCA) was performed with standardized data using the $z$-score.

\section{RESULTS}

The results obtained are presented in Figure 2; the ranges of concentrations were, in $\mathrm{mg} \mathrm{kg}^{-1}$ d.w.: Al 5,655 to 27,381; As 2 to 14 ; $\mathrm{Cd} 1$ to 13 ; $\mathrm{Cr} 5$ to 59 ; $\mathrm{Cu} 38$ to 20,$241 ; \mathrm{Ni} 4$ to 30 ; $\mathrm{Pb}$ 3 to 1,053 , and $\mathrm{Zn} 40$ to 2,813 . The results were compared with the CONAMA Resolution 420 of the Brazilian Environmental Council guidance values for soils (Conselho Nacional do Meio Ambiente [CONAMA], 2009), where only Al, As and Cr did not exceed the reference values. The levels of $\mathrm{Cd}, \mathrm{Cu}, \mathrm{Pb}$, and $\mathrm{Zn}$, between 2012 and 2016, exceeded the values of prevention (VP). $\mathrm{Ni}$ exceeded the VP only in 2013 at point 9. The levels of $\mathrm{Cd}, \mathrm{Cu}$, $\mathrm{Pb}$, and $\mathrm{Zn}$, exceeded the research values (RV), especially at points close to the CFAS, between 2012 and 2016. In the year 2018, only $\mathrm{Cu}$ and $\mathrm{Zn}$ exceeded the VP.

The ANOVA only with points close to CFAS (\#5, \#6, \#7, and \#9) during the period 2012-2018, demonstrated that the location did not influence metal levels $(p=0.12)$, despite the high levels of $\mathrm{Cd}, \mathrm{Ni}$, and $\mathrm{Zn}$ at point \#9, located inside the CFAS. While the year of sampling significantly influenced metal levels $(p=0.000)$. 
Al

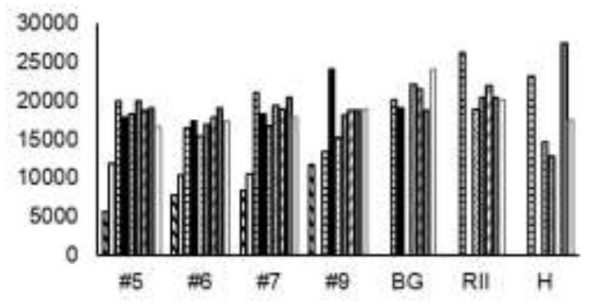

Cd
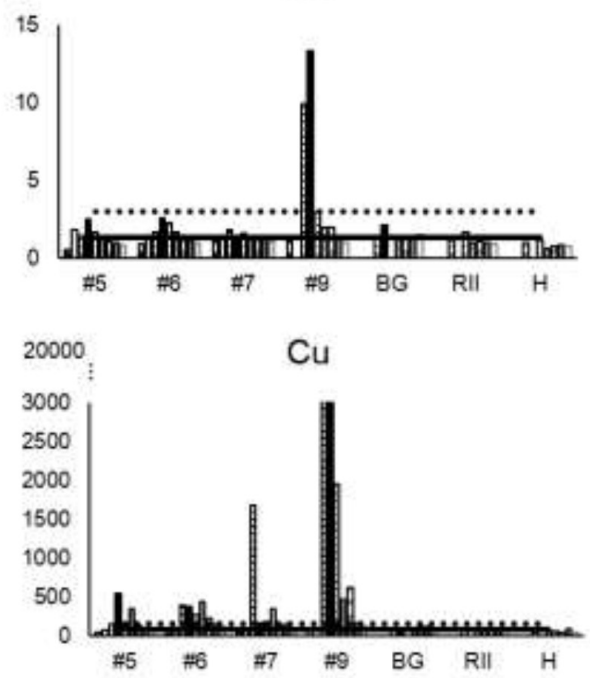

$\mathrm{Pb}$

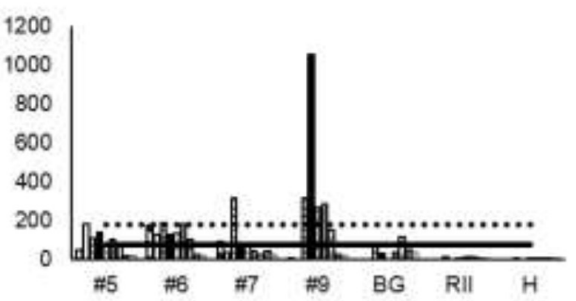

As

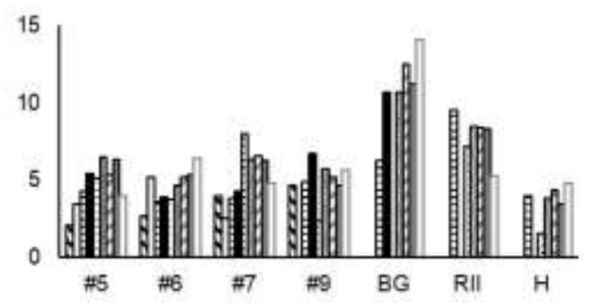

$\mathrm{Cr}$

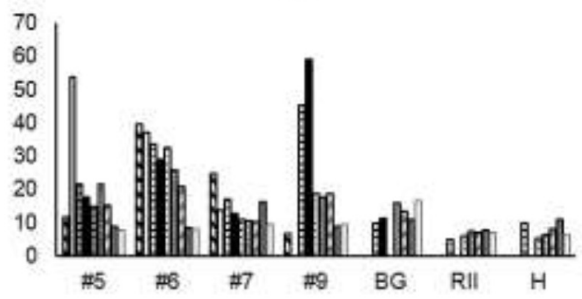

$\mathrm{Ni}$

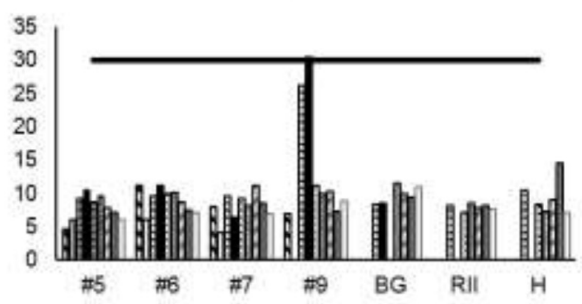

Zn

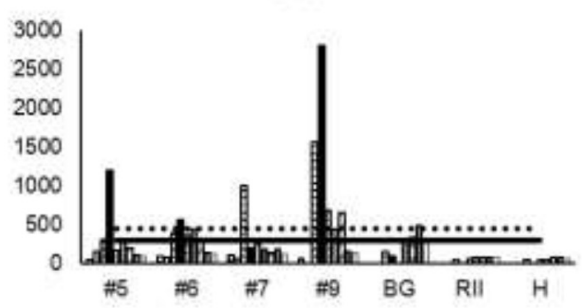

2013b $2014 \square 2015$

RV

FIGURE 2 | Metals (Al, Cd, Cr, Cu, Ni, Pb, and Zn) and arsenic (As) concentrations (in mg kg ${ }^{-1}$ ) in soil samples from the Commandant Ferraz Antarctic Station (CFAS, points \#5, \#6, \#7, and \#9), Base G (BG), Refuge II (RII), and Hennequin (H) between 2012 and 2018. Lines indicate prevention values (PV) and research values (RV) from the CONAMA Resolution 420/2009.

The highest levels of $\mathrm{Cd}, \mathrm{Cr}, \mathrm{Ni}$, and $\mathrm{Zn}$ were obtained in the year 2013b differing from all sampling years. The Al levels in 2012 were lower than the subsequent years, and the As levels in 2015 and 2018 were higher.

ANOVA with points close to CFAS (\#5, \#6, \#7 and \#9), including Base G, Refuge II, and Hennequin during the period 2013-2018, demonstrated that metal levels varied significantly depending on the location and year of sampling $(p=0.0000$ and $p=0.0004$, respectively). Arsenic levels at Base G in 2018 were highest among all sites and years studied, and As levels at Refuge II were higher than at points \#6 and \#9. The highest levels of Cd and $\mathrm{Ni}$ at point $\# 9$ differed from all locations. $\mathrm{Zn}$ and $\mathrm{Pb}$ at point \#9 differed from points far from CFAS (RII and $\mathrm{H}$ ), and $\mathrm{Pb}$ also differed from Base G. Cr at points around CFAS (\#5, \#6, and \#7) were higher than points \#9, Base G, Refuge II, and Hennequin. The highest levels of $\mathrm{Cd}, \mathrm{Cr}, \mathrm{Ni}, \mathrm{Zn}$, and $\mathrm{Pb}$ were obtained in the 


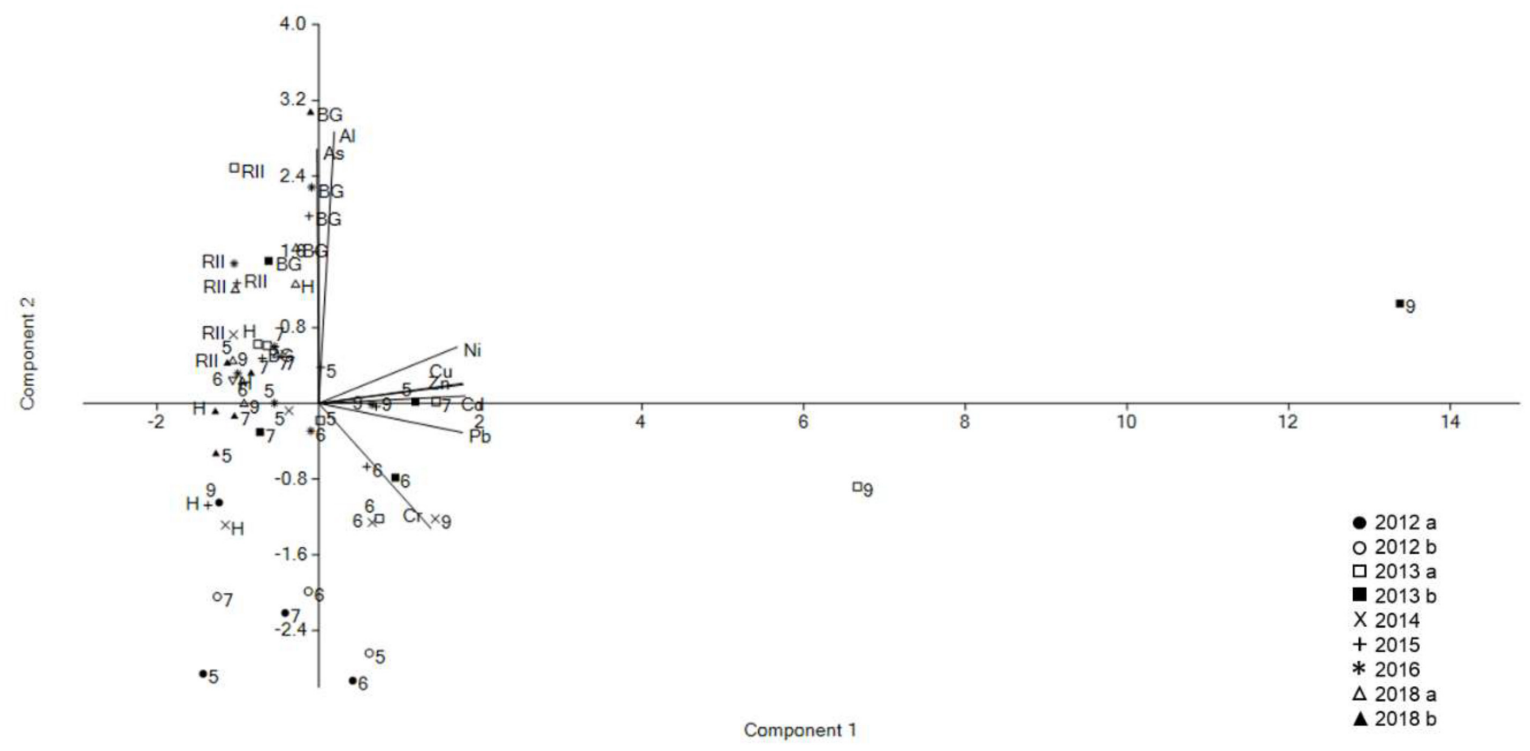

FIGURE 3 | Principal component analysis for metals (Al, Cd, Cr, Cu, Ni, Pb, and Zn) and arsenic (As) in soil samples from the Commandant Ferraz Antarctic Station (CFAS, points \#5, \#6, \#7, and \#9), Base G (BG), Refuge II (RII), and Hennequin (H) between 2012 and 2018.

year 2013b differing from all other sampling years, especially 2018 when the values reduced.

The principal component analysis explained $84 \%$ variance (Figure 3); it was possible to verify that $\mathrm{Al}$ and As related to Base G. The soil of the Refuge II and Hennequin points showed no association with metals. $\mathrm{Cd}, \mathrm{Cu}, \mathrm{Ni}$, and $\mathrm{Zn}$ related to the year of 2013b, 2015, and 2016; $\mathrm{Pb}$ related to 2013a to 2016, and Cr related to the years of 2012 to 2015 , all related to points near the CFAS, especially at sample \#9 (inside the CFAS).

\section{DISCUSSION}

The results obtained demonstrate that only $\mathrm{Al}$, As, and $\mathrm{Cr}$ did not exceed the reference values for soils (citealpBR10). Al levels increased between 2012 and 2018, especially at CFAS points. Despite this, the mean values of $\mathrm{Al}$ in the CFAS $\left(16,455.5 \pm 4,083.3 \mathrm{mg} \mathrm{kg}^{-1}\right)$ were lower than at Base $G$ $\left(20,913.4 \pm 2,022.9 \mathrm{mg} \mathrm{kg} \mathrm{mg}^{-1}\right)$ and at points far from the Brazilian station (Refuge II: $21,320.1 \pm 2,561.8 \mathrm{mg} \mathrm{kg}^{-1}$ and Hennequin: 19,365.0 $\pm 5,473.0 \mathrm{mg} \mathrm{kg}^{-1}$ ). Also, when compared to previous studies, Al levels were lower, such as in soil from CFAS (34,400 $\mathrm{mg} \mathrm{kg}^{-1}$; Santos et al., 2005) and McMurdo Station $\left(74,550 \pm 53,467 \mathrm{mg} \mathrm{kg}^{-1}\right.$; Crockett, 1998), which indicates that the levels obtained in the present study are natural for King George Island. The high levels of $\mathrm{Al}$ in soils might be related to abundant volcanic rocks of pyrite/chalcopyrite (Santos et al., 2005). The Hennequin soil differs from other study areas by the presence of higher plant species and a skua field (Vieira et al., 2012). Thus, Al levels in the soil may be related to the presence of seabirds in the region, as found in Arctowski (Ferrari et al., 2021).

As levels did not exceed the reference values of Brazilian legislation, but present mean values higher than previous studies in Antarctica as baseline studies in gray soil at McMurdo Station (<2.6 mg kg-1; Crockett, 1998), in human-affected soils on Fildes Peninsula $\left(2.01 \pm 0.98 \mathrm{mg} \mathrm{kg}^{-1}\right.$; Abakumov et al., 2017) and in pristine sites on Elephant Island $\left(0.71 \pm 0.35 \mathrm{mg} \mathrm{kg}^{-1}\right.$; Abakumov et al., 2017). The lowest average values were obtained in Hennequin $\left(3.7 \pm 1.2 \mathrm{mg} \mathrm{kg}^{-1}\right)$, a point far from research stations, similar to the natural level of As reported in Potter Cove $\left(3.8 \pm 0.1 \mathrm{mg} \mathrm{kg}^{-1}\right.$; Farías et al., 2007). CFAS showed mean As levels of $4.8 \pm 1.4 \mathrm{mg} \mathrm{kg}^{-1}$, with higher values in 2015 and 2018, similar to Artigas Base (Bueno et al., 2018) and soils oil tanks of Jubany Base (Farías et al., 2007). Those in Refuge II $\left(7.8 \pm 1.5 \mathrm{mg} \mathrm{kg}^{-1}\right)$ were higher than at points \#6 and \#9 (CFAS). The highest mean As levels were obtained at Base G (10.9 $\pm 2.6 \mathrm{mg} \mathrm{kg}^{-1}$ ), between 2016 and 2018, this punctual As enrichment may be related to the use of Base $G$ during the construction of the new station Antarctica, inaugurated in 2020, which generated waste. Furthermore, the bioaccumulation of As in the Antarctic biota has been attributed to a natural process due to the geologic composition of the area, dominated by basalt-andesite, not related to anthropogenic contamination (Farías et al., 2007).

Cr had the highest mean value in CFAS $\left(20.5 \pm 13.3 \mathrm{mg} \mathrm{kg}^{-1}\right)$ and at points around CFAS (\#5, \#6, and \#7) were higher than points \#9. The mean levels of $\mathrm{Cr}$ in Base $\left.\mathrm{G} 13.1 \pm 2.8 \mathrm{mg} \mathrm{kg}^{-1}\right)$, Refuge II $\left(6.7 \pm 1.0 \mathrm{mg} \mathrm{kg}^{-1}\right)$, and Hennequin $(7.8 \pm 2.3 \mathrm{mg}$ $\mathrm{kg}^{-1}$ ) were similar to the mean value obtained in Base Artigas, Fildes Peninsula $\left(10.3 \pm 8.1 \mathrm{mg} \mathrm{kg}^{-1}\right)$. There was an increase in $\mathrm{Cr}$ concentrations in 2012 at CFAS, 15 and 30 days after the fire, possibly a product of the accident as suggested in the study by Guerra et al. (2013), from metal structures and oil contamination (Alam and Sadiq, 1993; Padeiro et al., 2016). In the other years and places studied, the average values were lower than those obtained in several regions of Antarctica, such as: South Shetland 
islands, including King George Island (40 $\mathrm{mg} \mathrm{kg}^{-1}$; Santos et al., 2005), Fildes Peninsula (31.95 $\pm 13.82 \mathrm{mg} \mathrm{kg}^{-1}$, Lu et al., 2012) and Robert Island (72 $\pm 2 \mathrm{mg} \mathrm{kg}^{-1}$, Lima Neto et al., 2017); Ross Island at McMurdo Station (172 $\pm 38.6 \mathrm{mg} \mathrm{kg}^{-1}$; Crockett, 1998); and on the Antarctic Peninsula, on O'Higgins Base $\left(65 \mathrm{mg} \mathrm{kg}^{-1}\right.$; Celis et al., 2015).

The levels of $\mathrm{Cd}, \mathrm{Cu}, \mathrm{Ni}, \mathrm{Pb}$, and $\mathrm{Zn}$ exceeded the values of prevention (VP, Conselho Nacional do Meio Ambiente [CONAMA], 2009), and $\mathrm{Cd}, \mathrm{Cu}, \mathrm{Pb}$, and $\mathrm{Zn}$ exceeded the research values (RV, Conselho Nacional do Meio Ambiente [CONAMA], 2009) in CFAS, between 2012 and 2016, with highest levels in the year 2013b, 1 year and 10 months after the fire, these results highlight the sustainability of soil functions in the CFAS region.

The highest concentrations of $\mathrm{Cd}$ were obtained in CFAS and Base $G$, with mean values of $2.1 \pm 2.5 \mathrm{mg} \mathrm{kg}^{-1}$ and $1.5 \pm 0.3 \mathrm{mg} \mathrm{kg}^{-1}$, respectively. In Refuge II had an average of $1.1 \pm 0.3 \mathrm{mg} \mathrm{kg}^{-1} 1$ of $\mathrm{Cd}$ and Hennequin $0.8 \pm 0.2 \mathrm{mg} \mathrm{kg}^{-1}$ of $\mathrm{Cd}$. With the exception of Hennequin, the mean values of $\mathrm{Cd}$ obtained in this study are about 10 times higher than the values obtained in the soil of pristine sites on Elephant Island (0.22 $\pm 0.10 \mathrm{mg} \mathrm{kg}^{-1}$; Abakumov et al., 2017) from McMurdo Station (0.13 $\pm 0.023 \mathrm{mg} \mathrm{kg}^{-1}$; Crockett, 1998); and from Robert Island, near the Luis Risopatrón refuge $\left(<0.2 \mathrm{mg} \mathrm{kg}^{-1}\right.$; Lima Neto et al., 2017). Furthermore, they exceed the levels of Cd found on Fildes Peninsula (Lu et al., 2012; Abakumov et al., 2017), including near fuel tanks ( $0.5 \mathrm{mg} \mathrm{kg}^{-1}$; Amaro et al., 2015), and on the soil of King George Island penguin colonies (Cipro et al., 2018). This demonstrate the contamination of the CFAS, Base G, and Refuge II region by this metal that even at low concentrations is considered a pollutant for the biota (Farías et al., 2002). Cd may come from atmospheric transport, as it is a product of several industries and in agriculture, but it may also be related to the accident at CFAS, as it is an element present in batteries, metallic parts and paints (Wuana and Okieimen, 2011). Cd levels were lower than those obtained in the Antarctic Peninsula, at O'Higgins Base (65 mg kg-1; Celis et al., 2015), and Hope Bay (47 $\mathrm{mg} \mathrm{kg}^{-1}$; Bueno et al., 2011), being related to the volcanic activity of the region and contamination with oil, coal, alloys, and feces of penguin colonies.

Mean $\mathrm{Cu}$ levels in soil from South Shetland islands in past studies ranged from $22.28 \pm 4.40 \mathrm{mg} \mathrm{kg}^{-1}$ in Elephant Island, pristine soil in 2001, to $186.33 \pm 36.00 \mathrm{mg} \mathrm{kg}^{-1}$ in Fildes Peninsula, human-affected soils in 2009 (Abakumov et al., 2017). The average values found in Base $\mathrm{G}\left(95.6 \pm 20.6 \mathrm{mg} \mathrm{kg} \mathrm{kg}^{-1}\right.$ ), Refuge II $\left(83.7 \pm 8.1 \mathrm{mg} \mathrm{kg}^{-1}\right)$, and Hennequin $(51.2 \pm 13.9 \mathrm{mg}$ $\mathrm{kg}^{-1}$ ) are in the same range as those found on Fildes Peninsula (Lu et al., 2012; Abakumov et al., 2017; Bueno et al., 2018), and Robert Island (Lima Neto et al., 2017), being related to sewage contamination. Also, the high concentration of $\mathrm{Cu}$ in soils and sediments from Admiralty Bay, King George Island, can be associated with the mineralization of chalcopyrite (sulfide of $\mathrm{Cu}$ and $\mathrm{Fe}$ ) and in the area due to the mineralogy, from the glacial erosion of volcanic rocks, such as basalt-andesite (Fourcade, 1960; Machado et al., 2001). In the CFAS region, the mean $\mathrm{Cu}$ value that can be considered a base level, obtained in the summer of 2002-2003, was $44 \mathrm{mg} \mathrm{kg}^{-1}$ (Santos et al., 2005). While the mean $\mathrm{Cu}$ value found in the present study was $1,054.4 \pm 3,535.5 \mathrm{mg} \mathrm{kg}^{-1}$, with higher levels at point \#9 between 2013 and 2014, and at point \#7 only in 2013a, 1 year after the accident. This result is 100 times higher than the maximum values reported for this element in the Antarctic region (Lu et al., 2012; Abakumov et al., 2017; Lima Neto et al., 2017), demonstrating the anthropogenic contribution that has been related to associated sewage outfalls, oil spills, and waste (Negri et al., 2006; Tin et al., 2009).

$\mathrm{Ni}$ showed similar levels between the studied sites with a mean of $9.5 \pm 5.1 \mathrm{mg} \mathrm{kg}^{-1}$ for CFAS, $9.8 \pm 1.3 \mathrm{mg} \mathrm{kg}^{-1}$ for Base G, $7.9 \pm 0.5 \mathrm{mg} \mathrm{kg}^{-1}$ for Refuge II, and $9.4 \pm 2.8 \mathrm{mg}$ $\mathrm{kg}^{-1}$ for Hennequin. Ni presented a higher concentration at point \#9 (inside CFAS) in 2013, which exceeded VP (Conselho Nacional do Meio Ambiente [CONAMA], 2009). The results were slightly higher than those obtained in a pristine location at Elephant Island (3.58 $\pm 1.25 \mathrm{mg} \mathrm{kg}^{-1}$; Abakumov et al., 2017), at CFAS (5.1 mg kg-1; Santos et al., 2005) and at the Artigas Base (6.0 $\pm 2.9 \mathrm{mg} \mathrm{kg}^{-1}$; Bueno et al., 2018), demonstrating slight $\mathrm{Ni}$ enrichment related to batteries, electronic equipment, and fossil fuel burning (Wuana and Okieimen, 2011). Furthermore, we observed that the $\mathrm{Ni}$ values in the present study are lower than those found at Ross Island, at McMurdo Station (98 $\pm 26.4 \mathrm{mg}$ $\mathrm{kg}^{-1}$; Crockett, 1998) and at O'Higgins Base, in the Antarctic Peninsula (28 $\mathrm{mg} \mathrm{kg}^{-1}$; Celis et al., 2015), regions that present enrichment of this metal due to volcanic activity.

With an average value of $132.5 \pm 182.6 \mathrm{mg} \mathrm{kg}^{-1}, \mathrm{~Pb}$ presented higher concentrations in CFAS at point \#5 in 2012b, point \#6 in 2012a, point \#7 in 2013a, and point \#9 from 2013 to 2015. The highest levels of $\mathrm{Pb}$, at point $\# 9$, are consistent with the places where research equipment composed of $\mathrm{Pb}$ alloy and the generator in the CFAS were stored (Trevizani et al., 2016b). This result corroborates what was highlighted by Guerra et al. (2013), and points to the need for remediation, since the level of this metal has increased 100 times in relation to the CFAS soil in 2002-2003 (11.5 mg kg-1; Santos et al., 2005). Regarding the Antarctic soil, $\mathrm{Pb}$ levels are lower than those obtained in humanaffected soils from Fildes Peninsula (203.16 $\pm 49.91 \mathrm{mg} \mathrm{kg}^{-1}$; Abakumov et al., 2017), next to the Russian base Bellingshausen Station, and is related to hydrocarbon spills. The soil at BG presented an average of $53.6 \pm 32.7 \mathrm{mg} \mathrm{kg}^{-1}$ of $\mathrm{Pb}$, with higher concentration in 2016, which may be related to residues from the construction of the new station, as it is a component of paints, plumbing materials and soldering (Kennicutt et al., 2010). Points far from CFAS, Refuge II and Hennequin, had mean Pb levels of $7.4 \pm 1.1 \mathrm{mg} \mathrm{kg}^{-1}$ and $4.1 \pm 0.8 \mathrm{mg} \mathrm{kg}^{-1}$, respectively. These points did not show pollution and have levels similar to those obtained in a study considered to be based at McMurdo Station (5.8 $\pm 2.4 \mathrm{mg} \mathrm{kg}^{-1}$; Crockett, 1998).

$\mathrm{Zn}$ presented a mean value of $395.4 \pm 539.4 \mathrm{mg} \mathrm{kg}^{-1}$ in the CFAS, with higher levels at point \#5 in 2013b, and at point \#9 in 2013 (a and b), which differ from points far from CFAS (Refuge II and Hennequin). At Base $\mathrm{G}$ the higher levels of $\mathrm{Zn}$ were obtained between 2015 and 2018, with mean values of $281.0 \pm 141 \mathrm{mg} \mathrm{kg}^{-1}$. These $\mathrm{Zn}$ values are similar to those 
obtained from O'Higgins Base (300 mg kg-1 ; Celis et al., 2015). But they exceed, about twice, the values obtained in several places that house research stations and are affected by human activities, such as Artigas Antarctic Scientific, McMurdo Station, Luis Risopatrón refuge, and China Great Wall Base (Crockett, 1998; Amaro et al., 2015; Abakumov et al., 2017; Lima Neto et al., 2017). The levels of $\mathrm{Zn}$ in CFAS and Base G, can be related to sewage, batteries, paints, electrical device, and metallic structures (Tin et al., 2009), resulting from the station fire and the construction of the new station. Refuge II and Hennequin presented higher concentrations between 2013 and 2018, with average values of $69.0 \pm 9.8 \mathrm{mg} \mathrm{kg}^{-1}$ and $58.6 \pm 14.1 \mathrm{mg}$ $\mathrm{kg}^{-1}$, respectively. These values are slightly higher than those considered as the base level for the CFAS (52 $\mathrm{mg} \mathrm{kg}^{-1}$; Santos et al., 2005) and very similar to those obtained on Fildes Peninsula between 2009 and 2010 (58.69 $\pm 9.36 \mathrm{mg} \mathrm{kg}^{-1}$; Lu et al., 2012), demonstrating low $\mathrm{Zn}$ enrichment in regions far from the CFAS. Also, high values of $\mathrm{Zn}$ in soils and sediments from Admiralty Bay, King George Island, can be associated with the area due to the mineralogy, from the glacial erosion of volcanic rocks, such as basalt-andesite, which are composed of olivine, pyroxene and plagioclase that during the magmatic distinction process incorporate Zn (Fourcade, 1960; Salomons and Förstner, 1984; Machado et al., 2001).

Overall, the highest levels of $\mathrm{Cd}, \mathrm{Cr}, \mathrm{Cu}, \mathrm{Ni}, \mathrm{Pb}$, and $\mathrm{Zn}$ were related to the year of 2013b, 2015, and 2016; $\mathrm{Pb}$ related with 2013 - 2016, and Cr related to the years of 2012-2015, all related to points near the CFAS (Figure 3). As a consequence of the accident that occurred in 2012, these metals of anthropogenic origin presented enrichment in the soil surrounding the CFAS, especially at point \#9, which stands out for the highest levels of metals and was located within the CFAS, where the generator was located (Trevizani et al., 2016b). This enrichment may be associated with the battery bank, alloys, and various laboratory reagents; burning fuels; sewages outfalls; the composition of the painting used in the former station; and residues from the construction of the new station, which were eventually absorbed by the environment (Negri et al., 2006; Trevizani et al., 2016b). The results of 2018 demonstrated the reduction of the levels of all studied metals near CFAS, with only $\mathrm{Cu}$ and $\mathrm{Zn}$ exceeding the VP (Conselho Nacional do Meio Ambiente [CONAMA], 2009). This reduction may be related with the recovery of the soil, its turning during the construction of the new station or to the leaching of metals into Admiralty Bay; thus giving importance to continued monitoring of soil, sediments and Antarctic biota. Al and As were associated with Base $\mathrm{G}$, with natural provenance and related to the use of the base to support the construction of the new CFAS. The soil at the Refuge II and Hennequin points presented less enrichment of metals and were below the Brazilian legislation levels; this demonstrate that the soil of this region supports their function; being considered as control points for this region.

A study showed that contamination of the soil and consequently of sediments can affect benthic organisms, having reached the integrity of the marine ecosystem within a few hundred meters of the coast of the McMurdo research station (Kennicutt et al., 2010). Thus, knowing the contamination of Antarctic soil is crucial, since metals and metalloids can reach different environments as a consequence of run-off events (Celis et al., 2015), reaching aquatic biota and being incorporated into the terrestrial food web. Therefore, future studies of monitoring of soil, sediments and Antarctic biota around the CFAS are essential for the proper management and preservation of this ecosystem of international importance.

\section{CONCLUSION}

This study represents an update overview of the environmental impacts around the area of the CFAS following the accidental fire that destroyed the main buildings of the station complex in 2012. CFAS between 2012 and 2016 showed increase in the concentrations of $\mathrm{Cd}, \mathrm{Cu}, \mathrm{Ni}, \mathrm{Pb}$, and $\mathrm{Zn}$, exceeding the levels indicated in Brazilian legislation, representing potential risk to the sustainability of soil functions and to human health. These metals related to anthropogenic activities, together with $\mathrm{Cr}$, seem to be mainly related to the residues of the fire that destroyed the station. They are present at high levels when compared to previous studies in the Antarctic environment, with emphasis on point \#9 (inside the CFAS). Al and As were associated with Base $G$, with natural provenance and related to the use of the base to support the construction of the new CFAS. The soil at the Refuge II and Hennequin points, distant from the CFAS, presented less enrichment of metals, demonstrating that the soil of this region supports their function; being considered as control points for this region. The results of 2018 demonstrated the reduction of the levels of the majority of the studied metals near to CFAS, demonstrating that despite the contamination caused by the accident, the soil is in recovery or related to the leaching of metals to Admiralty Bay, indicating a need for the continue monitoring of soil, sediments, and Antarctic biota.

\section{DATA AVAILABILITY STATEMENT}

The original contributions presented in the study are included in the article/supplementary material, further inquiries can be directed to the corresponding author.

\section{AUTHOR CONTRIBUTIONS}

TT contributed to the chemical analyses and wrote the article. RM provided the sample collection and resources and performed the supervision. RF performed the supervision and provided the resources. All authors commented and reviewed on the manuscript.

\section{FUNDING}

Financial support was provided by the Brazilian Ministry of the Environment (MMA) as part of the agreement "Environmental monitoring in the direct influence area of the Brazilian Antarctic Station" (SBF/MMA009/2012). The Brazilian Antarctic Program (PROANTAR) provided logistic support in Antarctica. 


\section{REFERENCES}

Abakumov, E., Lupachev, A., and Andreev, M. (2017). Trace element content in soils of the King George and Elephant islands, maritime Antarctica. Chem. Ecol. 33, 856-868. doi: 10.1080/02757540.2017.1384821

Alam, I. A., and Sadiq, M. (1993). Metal concentrations in Antarctic sediments samples collected during the Trans-Antarctica 1990 expedition. Mar. Pollut. Bull. 26, 523-527. doi: 10.1016/0025-326x(93)90472-v

Amaro, E., Padeiro, A., Mão de Ferro, A., Mota, A. M., Leppe, M., Verkulich, S., et al. (2015). Assessing trace element contamination in Fildes Peninsula (King George Island) and Ardley Island, Antarctic. Mar. Pollut. Bull. 97, 523-527. doi: 10.1016/j.marpolbul.2015.05.018

Bargagli, R. (2008). Environmental contamination in Antarctic ecosystems. Sci. Total Environ. 400, 212-226. doi: 10.1016/j.scitotenv.2008.06.062

Bölter, M. (2011). Soil development and soil biology on King George Island, Maritime Antarctic. Pol. Polar Res. 32, 105-116. doi: 10.2478/v10183-0110002-z

Bueno, C., Kandratavicius, N., Venturini, N., Figueira, R. C. L. F., Pérez, L., Iglesias, K., et al. (2018). An evaluation of trace metal concentration in terrestrial and aquatic environments near Artigas Antarctic Scientific Base (King George Island, Maritime Antarctica). Water Air Soil Pollut. 229:398. doi: 10.1007/ s11270-018-4045-1

Bueno, M., Schaefer, G., De Freitas, P., Simas, F., Pereira, T., and Rodrigues, E. (2011). Heavy metals contamination in century-old man-made technosols of Hope Bay, Antarctic Peninsula. Water Air Soil Pollut. 222, 91-102. doi: 10.1007/ s11270-011-0811-z

Celis, J. E., Barra, R., Espejo, W., González-Acuña, D., and Jara, S. (2015). Trace element concentrations in biotic matrices of Gentoo Penguins (Pygoscelis Papua) and coastal soils from different locations of the Antarctic Peninsula. Water Air Soil Pollut. 226:2266. doi: 10.1007/s11270-014-2266-5

Cipro, C. V. Z., Bustamante, P., Petry, M. V., and Montone, R. C. (2018). Seabird colonies as relevant sources of pollutants in Antarctic ecosystems: part 1 - Trace elements. Chemosphere 204, 535-547. doi: 10.1016/j.chemosphere.2018.02.048

Conselho Nacional do Meio Ambiente [CONAMA] (2009). Resolução $n^{\circ}$ 420, 2009. Brasília: Ministry of the Environment, Brazil.

Crockett, A. B. (1998). Background levels of metals in soils, McMurdo station, Antarctica. Environ. Monit. Assess. 50, 289-296. doi: 10.1023/A:100583710 0718

Farías, S., Arisnabarreta, S. P., Vodopivez, C., and Smichowski, P. (2002). Levels of essential and potentially toxic trace metals in Antarctic macro algae. Spectrochim. Acta Part B 57, 2133-2140. doi: 10.1016/s0584-8547(02)00183-0

Farías, S., Smichowski, P., Vélez, D., Montoro, R., Curtosi, A., and Vodopívez, C. (2007). Total and inorganic arsenic in Antarctic macroalgae. Chemosphere 69, 1017-1024. doi: 10.1016/j.chemosphere.2007.04.049

Ferrari, F. R., Schaefer, C. E. G. R., Pereira, A. B., Thomazini, A., Schmitz, D., and Francelino, M. R. (2021). Coupled soil-vegetation changes along a topographic gradient on King George Island, maritime Antarctica. CATENA 198:105038. doi: $10.1016 /$ j.catena.2020.105038

Fourcade, N. H. (1960). Estudio Geológico y Petrográfico de Caleta Potter, Isla 25 de Mayo. Instituto Antártico Argentino, Publicación No. 8, Islas Shetland del Sur. Buenos Aires: Instituto Antártico Argentino, 115.

Guerra, M. B. B., Neto, E. L., Prianti, M. T. A., Pereira-Filho, E. R., and Schaefer, C. E. G. R. (2013). Post-fire study of the Brazilian scientific Antarctic Station: toxic element contamination and potential mobility on the surrounding environment. Microchem. J. 110, 21-27. doi: 10.1016/j.microc.2013.01.007

Hammer, O., Harper, D. A. T., and Ryan, P. D. (2001). PAST: paleontological statistics software package for education and data analysis. Palaeontol. Electron. 4:9.

Islam, M. S., and Tanaka, M. (2004). Impacts of pollution on coastal and marine ecosystems including coastal and marine fisheries and approach for management: a review and synthesis. Mar. Pollut. Bull. 48, 624-649. doi: 10. 1016/j.marpolbul.2003.12.004

Kennicutt, M., Klein, A., Montagna, P., Sweet, S., Wade, T., Palmer, T., et al. (2010). Temporal and spatial patterns of anthropogenic disturbance at McMurdo Station, Antarctica. Environ. Res. Lett. 5:034010. doi: 10.1088/1748-9326/5/3/ 034010

Lima Neto, E., Guerra, M. B. B., Thomazini, A., Daher, M., Andrade, A. M., and Schaefer, C. E. G. R. (2017). Soil contamination by toxic metals near an
Antarctic refuge in Robert Island, Maritime Antarctica: a monitoring strategy. Water Air Soil Pollut. 228:66. doi: 10.1007/s11270-017-3245-4

Lu, Z., Cai, M., Wang, J., Yang, H., and He, J. (2012). Baseline values for metals in soils on Fildes Peninsula, King George Island, Antarctica: the extent of anthropogenic pollution. Environ. Monit. Assess. 184, 7013-7021. doi: 10.1007/ s10661-011-2476-x

Machado, A., Lima, E. F., Chemale, F. Jr., Liz, J. D., and Ávila, J. N. (2001). Química mineral de rochas vulcânicas da Península Fildes (Ilha Rei George), Antártica. Rev. Bras. Geocienc. 31, 299-306. doi: 10.25249/0375-7536.2001313299306

Montone, R. C., Taniguchi, S., and Weber, R. R. (2001). Polychorinated biphenyls in marine sediments of Admiralty Bay, King George Island, Antarctica. Mar. Pollut. Bull. 42, 611-614. doi: 10.1016/S0025-326X(01)00092-3

Navas, A., López-Martínez, J., Casas, J., Machín, J., Durán, J. J., Serrano, E., et al. (2008). Soil characteristics on varying lithological substrates in the South Shetland Islands, maritime Antarctica. Geoderma 144, 123-139. doi: 10.1016/j. geoderma.2007.10.011

Negri, A., Burns, K., Boyle, S., Brinkman, D., and Webster, N. (2006). Contamination in sediments, bivalves and sponges of McMurdo Sound, Antarctica. Environ. Pollut. 143, 456-467. doi: 10.1016/j.envpol.2005. 12.005

Padeiro, A., Amaro, E., Dos Santos, M. M., Araújo, M. F., Gomes, S. S., Leppe, M., et al. (2016). Trace element contamination and availability in the Fildes Peninsula, King George Island, Antarctica. Environ. Sci. Process. Impacts 18, 648-657. doi: 10.1039/c6em00052e

Ribeiro, A. P., Figueira, R. C. L., Martins, C. C., Silva, C. R. A., França, E. J., Bícego, M. C., et al. (2011). Arsenic and trace metal contents in sediment profiles from the Admiralty Bay, King George Island, Antarctica. Mar. Pollut. Bull. 62, 192-196. doi: 10.1016/j.marpolbul.2010.10.014

Salomons, W., and Förstner, U. (1984). Metals in the Hydrocycle. Berlin: Springer Verlag, 349.

Santos, I. R., Silva-Filho, E. V., Schaefer, C. E., Albuquerque Filho, M. R., and Campos, L. S. (2005). Heavy metals contamination in coastal sediments and soils near the Brazilian Antarctic Station, King George Island. Mar. Pollut. Bull. 50, 185-194. doi: 10.1016/j.marpolbul.2004.10.009

Schaefer, C. E., Francelino, M. R., Simas, F. N., and Costa, L. M. (2004). “Geologia e geotectônica da Península Keller, Antártica marítima," in Ecossistemas Costeiros e Monitoramento Ambiental da Antártica Marítima, Baía do Almirantado, Ilha Rei George, eds C. E. Schaefer, M. R. Francelino, F. N. Simas, and M. R. Albuquerque- Filho (Viçosa: NEPUT), 7-13.

Tin, T., Fleming, Z. L., Hughes, K. A., Ainley, D. G., Convey, P., Moreno, C. A., et al (2009). Review impacts of local human activities on the Antarctic environment. Antarct. Sci. 21, 3-33. doi: 10.1017/S0954102009001722

Trevizani, T. H., Figueira, R. C. L., Ribeiro, A. P., Theophilo, C. Y. S., Majer, A. P., Petti, M. A. V., et al. (2016a). Bioaccumulation of heavy metals in marine organisms and sediments from Admiralty Bay, King George Island, Antarctica. Mar. Pollut. Bull. 106, 366-371. doi: 10.1016/j.marpolbul.2016.02.056

Trevizani, T. H., Silva, C. R. A., Majer, A. P., Ribeiro, A. P., Ferreira, P. A. L., Montone, R. C., et al. (2016b). Arsenic and heavy metals in soil from Comandante Ferraz Antarctic Station (King George Island) after fire. INCT APA Annu. Act. Rep. 2014, 25-29. doi: 10.4322/apa.2016.008

Trevizani, T. H., Petti, M. A. V., Ribeiro, A. P., Corbisier, T. N., and Figueira, R. C. L. (2018). Heavy metal concentrations in the benthic trophic web of Martel Inlet, Admiralty Bay (King George Island, Antarctica). Mar. Pollut. Bull. 130, 198-205. doi: 10.1016/j.marpolbul.2018.03.031

Underwood, A. J. (1997). Experiments in Ecology: Their Logical Design and Interpretation Using Analysis of Variance. Cambridge: Cambridge University Press.

United States Environmental Protection Agency [USEPA] (1996). Method 3050B. Acid Digestion of Sediments, Sludges and Soil. Revision 2. Washington, DC: USEPA.

Vieira, F. C. B., Antônio Batista Pereira, A. B., Schünemann, A. L., Albuquerque, F. V., Albuquerque, M. P., Putzke, J., et al. (2012). Soil chemical attributes as affected by vegetal cover and seabirds in Punta Hennequin, Antarctica. INCT APA Annu. Act. Rep. 57-61. doi: 10.4322/apa.2014.062

Vodopivez, C., Smichowski, P., and Marcovecchio, J. (2001). "Trace metals monitoring as a tool for characterization of Antarctic ecosystems and environmental management. The Argentine programme at Jubany Station," in Environmental Contamination in Antarctica: A Challenge to Analytical 
Chemistry, eds S. Caroli, P. Cescon, and D. W. H. Walton (Amsterdam: Elsevier), 406.

Wuana, R. A., and Okieimen, F. E. (2011). Heavy metals in contaminated soils: a review of sources, chemistry, risks and best available strategies for remediation. Int. Sch. Res. Netw. ISRN Ecol. 2011:402647. doi: 10.5402/2011/402647

Xu, Q., Chu, Z., Gao, Y., Mei, Y., Yang, Z., Huang, Y., et al. (2020). Levels, sources and influence mechanisms of heavy metal contamination in topsoils in Mirror Peninsula, East Antarctica. Environ. Pollut. 257:113552. doi: 10.1016/j.envpol. 2019.113552

Xuebin, Y., Xiaodong, L., Linguand, S., Renbin, Z., Zhouqing, X., and Yuhong, W. (2006). A 1500-year record of lead, copper, arsenic, cadmium, zinc level in Antarctic seal hairs and sediments. Sci. Total Environ. 371, 252-257. doi: 10.1016/j.scitotenv.2006. 07.022

Zhao, Y., and Li, T. (1996). The pedogenic groups and dignostic charateristics in the Fildes Peninsula of King George Island, Antarctica. Antarct. Res. 7, 70-78.
Conflict of Interest: The authors declare that the research was conducted in the absence of any commercial or financial relationships that could be construed as a potential conflict of interest.

Publisher's Note: All claims expressed in this article are solely those of the authors and do not necessarily represent those of their affiliated organizations, or those of the publisher, the editors and the reviewers. Any product that may be evaluated in this article, or claim that may be made by its manufacturer, is not guaranteed or endorsed by the publisher.

Copyright (C) 2022 Trevizani, Montone and Figueira. This is an open-access article distributed under the terms of the Creative Commons Attribution License (CC BY). The use, distribution or reproduction in other forums is permitted, provided the original author(s) and the copyright owner(s) are credited and that the original publication in this journal is cited, in accordance with accepted academic practice. No use, distribution or reproduction is permitted which does not comply with these terms. 